\title{
Legal Protection of Fishing Rights By Fishermen on Fishery Resource Conservation Activities in Indonesia
}

\author{
Yulia $^{1}$ \\ \{yulia.hasan@universitasbosowa.ac.id ${ }^{1}$ \} \\ Faculty of Law Bosowa University,Makassar, Indonesia ${ }^{1}$
}

\begin{abstract}
The purpose of this study was to determine the concept of legal protection of fishing by fishermen in conservation of fish resources in Indonesia and to analyze the factors that hinder fishermen's fishing rights in fish resource conservation activities. This research is normative juridical using qualitative analysis techniques. The results showed that the concept of legal protection for fishing by fishermen for conservation of fish resources in Indonesia is inseparable from international agreements that have been agreed by the Indonesian government. The protection of the conservation of fish resources in Indonesia is an implementation of an international agreement that regulates the conservation of fish resources and has been ratified by the Indonesian government. However, there are still several international agreements that have not been implemented into national law and this has an impact on the availability of fish resources, because they are taken by foreign fishermen and are detrimental to Indonesian fishermen. For this reason, cooperation agreements with other countries are needed to protect fish resources which are the right of fishermen. The results also show that the factors that hinder fishermen's fishing rights in the conservation of fish resources are human actions that have negative impacts that can damage the fishery environment, changes in government policies related to conservation area management, and weak law enforcement.
\end{abstract}

Keywords: Legal Protection, Rights Of Fishermen, Conservation Of Fish Resources.

\section{Introduction}

Fish is one of food source that has economic value and important for human life because the environment of the existence of fish resources can be made business land, one of them as a tourist attraction, conservation efforts through the conservation of fish resources and their ecosystems is the absolute obligation of each generation. The action of conserving the natural resources is done through environmental management, especially the marine environment, intended to preserve, protect the interests and welfare of future generations. Conservation cannot be separated by the management of fish resources and the environment as a whole.Considering the characteristics of fish resources and its environment has a high sensitivity both to the influence of global climate and seasonal climate as well as aspects of ecosystem linkage among local, regional, or global waters, crossing the boundaries of the country, in conserving management and development fish resources should be based on principles (article 2 paragraph (2)(1): caution with the support of scientific evidence,consideration of local wisdom, community-based management, integrated coastal area management, more capture prevention, development of fishing gear, and eco-friendly 
fishing methods, consideration of the economic condition of the community, and sustainable use of biodiversity.

Protection of fish resources cannot be separated from the various international instruments implemented by Indonesia in formulating rules on fishery resource management as UNCLOS 1982, UNFSA 1995,CCRF and others. Then implemented in law number 31 of 2004 on Fisheries junto law number 45 of 2009 concerning the amendment of Law Number 31 of 2004 concerning Fisheries, and other laws governing the importance of protecting fish and environmental resources. Fishery is the largest marine resource potential in the last decade (10 years) shows the existence of exploitation and exploration of fishery products Indonesia, and experienced a very hamful increase for Indonesia.According to the World Food ang Agricultural Agency (FAO) fishery crime activity called Illegal, Unregulated, and Unreported Fishing (IUU-Fishing, which means that fishing is done illegally not reported and not in accordance with established rules. (M.Natsir Jamil, 2015) (2).

FAO data staes that Indonesia's losses due to IUU Fishing are estimated to reach 30 trillion per year. FAO stated that the current stock of fish resources in the world that still allows for increased capture is only 20 percent, while 55 percent are in full utilization condition and the remaining 25 percent are in danger of sustainability. This is clarified with the statement of the Ministry of Marine and Fisheries that the loss rate is about 25 percent of the total owned by the potential of fisheries owned Indonesia of 1,6 million tons per year. Fishery conditions in this world do not very much with the conditions in Indonesia. (M.Natsir Jamil, 2015) (3). Based on these conditions as FAO member states, the government of Indonesia has an obligation to act and take responsibility in preventing, reducing and eliminating IUU Fishing, by implementing International Plan of Action to Prevent, Deter and Eliminate Illegal, Unreported, and Unregulatad Fishing (IPOA-IUU) into national law as a basis for taking preventive IUU Fishing.

Although international regulations regulate the importance of conserving fish resources undertaken by countries, the government of Indonesia in the conservation of fish resources faced with the problem of fish resources management are:economic policies tend to be more favorable to the exploitation of fish resources, resulting in weak institutional management and law enforcement. During this law enforcement of illegal fishing has not been able to realize protection in the context of the management and utilization of fish resources potential,as well as maintaining the territory of the sovereignty of the United Republic of Indonesia. Besides the application of the principles of sustainable development into the organizational system, as well as work programs of government, both central and in the region is still not running properly.

Efforts to conserve fish resources should still be done through state regulations by protecting, utilizing and conserving fish resources, one of them by applying international agreements that have been ratified by the Indonesian government into national law as a form of cooperation and attention to prevent IUU Fishing. This is done given the resources of fish is a natural resource that must be protected and maintained for future generations.

Therefore, this paper aims: To know the concept of legal protection of fishing by fishermen on fishery resource conservation activities in Indonesia, to analyse factors that inhibit fishing rights by fishermen on fish resources conservation activities. This was the juridical normative research using the qualitative analysis technique. 


\section{Discussion}

\section{A. The Concept of Legal Protection of Fishing by Fishermen on The Conservation Activities of Fish Resources}

\section{International Treaties Governing The Conservation of Fish Resources}

The protection of fishing law by fishermen in Indonesia cannot be separated from several international agreements that have been ratified by the government as follows:

\subsection{Sea Law Convention 1982}

Stockholm Declaration 1972 is the development of modern international environmental law, meaning that since then the environmental law changed the nature of the use oriented to be environment oriented. Use-oriented environmental law that provides the right of the international community to exploit the environment and natural resources without imposing any obligation to maintain, protect, and preserve it. The legal products that existed before the birth of the Stockholm Declaration merely justified the human right to use the environment but did not require environmental protection. An environmentally oriented legal product is a legal product that not only gives people the right to use the environment but also burdens people with an obligation to safeguard, protect, and preserve it.The 1982 Sea Law Convention falls within an environment-oriented category.

A Sea Law Convention adopted in 1982 after 11 years of negotiations in UNCLOS III. Adopt a nautical sea institution 12 nautical miles and ZEE 200 miles. These institutions are a compromise between the wishes of some countries to expand the national maritime zone and the wishes of maritime nations to maintain the territorial sea within the 12 nautical miles.(Marcel Hendrapati, 2013:125-126) (4).

In relating to the utilization and management of fish resources, the Sea Law Convention of 1982 contains provisions relating to the applicable fisheries laws of various maritime zones which are below and beyond the limits of national jurisdiction. Provisions relating to the conservation of fish resources are provided for Article 61 of the 1982 Law of the Sea. In brief the objectives of fisheries conservation under Article 61 of The 1982 Law of The Sea Law are:

a. Sets the allow number of catches, (total allowable cacth) abbreviated as ATC;

b. Maintenance of biological resources in ZEE;

c. The population of the species captured, maintained in such a way or restored to the level that MSY can produce;

The sovereign rights of coastal states on biological natural resources in ZEE are offset by the obligation of coastal states of undertake conservation efforts. Acces is not allowed to other countries automatically, but it depends on what can be done between coastal countries with third countries, it is regulated in detail in article 62 from paragraph (3) to (5) of the 1982 Sea Law Convention.

Based on the above provisions, coastal states are required to take conservations measures by establishing the allowable amount of fish catch from fish resources contained in the exclusive economic zone.(Seokwoo Lee,2013)(5). Coastal states are required to maintain, on the basis of existing scientific evidence, so that fish resources do not over-exploited in order to ensure maximum sustainable yields.(Dikdik Mohamad Sodik, 2011:85) (6)

Article 4 Paragraph (1) of The law No.24 of 2000 on International Treaties states that the Government of Indonesia makes international treaties (with one or more countries or 
international organizations or other international legal subjects) by agreement and the parties are obliged to implement the agreement in good faith.(Muhammad Ashri.2012:82)(7)

Currently one of the main requirements to be considered in any fisheries management plan is adherence to international sanctions, and a prudent approach to management (precautionary approach to management). (Jesse Hasting, 2012) (8). Such obedience tends to be increasingly realized in the fishery policy of each country or the statutes of the organization in charge of coordinating the management of fisheries.

\subsection{The Convention on Biological Diversity 2010}

One of the outcomes of this convention is addressing the need for conservation and sustainable use of marine resources to tackle poverty, food security and livelihoods and promote economic growth. From 283 points of agreement, 19 points concerning marine and fisheries and three very important points, namely conservation, fisheries management and subsidies. The importance of marine conservation including marine protected areas and sustainable utilization is expressed in point 177 which refers to the Convention Biological Diversity of 2010 which targets 10 percent of coastal and marine areas by 2020 . When the Indonesian Sea reaches 3.1 million $\mathrm{km} 2$ (310 million hectares), then we must conserve 31 million hectares. To date our marine conservation area is about 15,4 million hectares (5 percen) and 2020 is targeted 20 million hectares.(Yusmanto, 2012) (10).

1.3. United Nations 1995 Agreement on The Implementation of The Provisions of The United Nations Convention on The Law of The Sea of 10 December Relating to The Conservation and Management of Straddling Fish Stocks and Highly Migratory Fish Stocks

United Nations consent of 1995 fish stock comprises 50 articles and two annexes,contains basic materials such as: under article 2 of this agreement aims to ensure the long-term conservation and sustainable use of straddling fish stocks and distant fish stocks and distant fish stocks through the effective implementation of the relevant provision of the convention.

According to Article 6 Paragraph (1) of The United Nations agreement, States should apply a broad precautionary approach to the conservation, management and exploitation of straddling fish stocks and highly migratory fish stocks. While Paragraph (2) of this agreement states that states are required to be more careful when information is uncertain or unreliable hshould not used as an excuse to delay or derail conservation measures and management of fish resources. The implementation of the prudential principle approach at the regional leel is in the Convention on the Conservation of Antartic Marine Living Resources (CCAMLR).CCAMLRis the first international treaty to contain prudential and ecosystem approaches as a basic principle for the conservation and management of marine biological resources.

Today there are five (5) regional fisheries organizations authorized to regulate the conservation and management of fish stocks, especially the world's tuna. Although special powers and responsibilities are different, but have the same authority to establish conservation and sustainable management measures for tuna stocks, the five organizations are:

a. The Conservation Convention of Southern Bluefin Tuna, Commission (CCSBT)

b. Inter-American Tropical Tuna Commision (IATTC).

c. The International Commission for the Conservation of Atlantic Tuna (ICCAT).

d. The Indian Ocean Tuna Comission (IOTC)

e. The Westren and Central Pacific for Fisheries Commision (WCPFC) 


\subsection{International Convention on International Trade in Endangered Species of Wild Fauna and Flora (CITES) 1973}

Provisions, International Convention on International Trade in Endangered Species of Wild Fauna and Flora (CITES) 1973, entered into force on 1 Juli 1975 within the framework of the law of trade in rare species. The purpose of CITES is establish a system of controlling trede is wild plants and wildlife and its products internationally. Such control is based on the fact that unlimited commercial exploitation of the survival of a species. (Guide Book, 2010:2)(11).

Indonesia has ratified CITES through Presidential Decree No.43 in 1978 about Convention On International Trade in Endengered Species of Wild Fauna And Flora, and as a consequence trade of vegetation and wildlife conducted by Indonesia is subject to the provisions os CITES. The ratification is stipulation or procedure that the convention has been in effect based on the stipulation of the two Presidential Decree No.43 in 1978.

\subsection{The 1995 FAO Code of Conduct for Responsible Fisheries}

The fundamental problem faced by marine fishery at present is the general tendency of decreasing fishery productivity in most waters area. This is exacerbated by the declining quality of the environment/habitat of fish and the high poverty rate of the population in some areas. On the other hand, the fishery continues to be the mainstay of food sources, especially animal protein, employment, beauty, recreation, trade, and various economic activities of the world community.

In the FAO conference on 31 October 1995, the principles generated in the Rio Summit were adopted into Code of Conduct for Responsible Fisheries (CCRF). In principle, the code is the basis of international standards for the conservation, management and development of fisheries as a whole. The basic standards include several settings, including rules about (1) arrest, (2) management, trade, and fishery products, (3) operational capture, (4) aquaculuture, (5) fisheries research, and (6) integration of various fisheries activities into the management of coastal areas. One of the most important issues in fisheries management is the limited property right. This is inseparable from the character of fish resources that is common properties and open access. The character of such resources is also exacerbated by the high uncertainty of fish resources, environment, market, and government policy, and then encourage the fisheries into various forms of unhealthy competition.

A management approach that provides space for the division of tasks and responsibilities between government and other stakeholders is referred to as management co. This management is defined as the decentralization of decision makers involving user groups (stakeholders) and governments. User groups in this case includefishermen, processors,fish traders, intermediaries (middleman), fishing gear suppliers, consumers, researchers, employees, government, law enforcement, environmental and conservationists, ,NGOs and others.

Co management is required on the basis of awareness that under other management approaches, effective processes for ensuring linkages between the public, private and public sectors have always failed to develop. Article 6 and 7 CCRF suggest the importance of stakeholder participation in effective fisheries management. For small scale fisheries management co is very important at least for the following reasons (Yohanes Widodo, 2008:195) (12)::

a. Local conditions and the historiy of kenelayanan business have significance as a pre condition of development of management co;

b. Proximity to the beach (which is fragile requires effective management 
c. The traditionally of management has proved inadequate to address the rate of improvement entry, capilatalization, and exploitation,

d. Communities have a responsibility for empowering conflict rules and resolutions, and

e. Small scale fisheries have local and regional interest that are often disproportionate to the size of fish resources. Co management effort by effectively linking the various stakeholders is one way to solve the problem of the resource management process.

Management of fishery resources is quite complicated when compared with other natural resource management, especially those that are territorial. Therefore fisheries management needs a goods plan that must be approach and supported by all those involved and stakeholders, is stakeholders. Involving all stakeholders, theirs obligations and responsibilities for long-term utilization and management of fish and ecosystem resources can be improved.

Although it does not have binding legal force, it provides guidance for all countries in the formulation of the measures necessary to ensure the management and utilization of fish resources in accordance with national legislation in the field of fisheries and the environment. CCRF provisions can be used as guidance in making laws and regulations concerning fisheries for the prevention and control of fishing activities that are not responsible in the form of fishing.

\subsection{International Plan of Action to Deter, Prevent and Eliminate Ilegal, Unreported and Unregulated Fishing (IPOA-IUU)2001}

IPOA-IUU formed as a non-binding international instrument within the framework of CCRF, to respond to the concerns of the $23^{\text {rd }}$ UN Food Agriculture Organization Fisheries Session Meeting in February 1999. The purpose of IPOA IUU is to prevent, reduce and eliminate IUU Fishing activities by providing guidance to all countries in developing comprehensive, effective and transparent steps in collaboration with competent regional fisheries management organizations. IPOA-IUU divides the steps that must be implemented based on (Dikdik Mohamad Sodik, 2014:195)(14):

a. The division of responsibilities between all countries, flag countries, flag ships, and coastal states ;

b. Measures agreed upon in international agreements on trade :

c. Responsibilities of regional fisheries management organizations;

Paragraph 10 IPOA IUU governs the responsibilities of all countries, to implement the provisions of international related to the regulation in the 1982 Sea Law Convention in the prevention, reduction and elimination of IUU Fishing. On the basis of that, all states under paragraph 11 are encouraged to ratify or ratify the 1982 Sea Law Convention and United Nations approval of fish stocks 1995. States which have not ratified or ratified both international instruments are prohibited from taking action against the provisions of the international instrument.

The existence of IUU IPOA has supplemented and supplemented the provisions of the 1982 Sea Law Convention and the UN Agreement on Fish Stock 1995 and CCRF. Most of the provisions contained there are drawn up under the provisions of the 1982 Sea Law Convention and United Nations consent on 1995 Fish Stock and CCRF. Although IPOA IUU only has the strength as a recommendation to all countries, it turns out IPOA IUU plays an important role in the establishment and development of international fisheries law as a legal system positive. IPOA IUU provides guidance to all countries in drafting national legislation on the prevention and reduction of IUU Fishing activities. 
The Indonesian Government in its effort to protect the conservation of fish resources, has signed several international agreement as described above. The purpose of international agreement , because the marine environment has the potential for diversity and high economic value, rich with fish resources that are beneficial to humans and the environment that can be used as a source of food and tourist attraction. Given its irreplaceable nature and an important role for life, conservation efforts through the conservation of fish resources and their ecosystems become the absolute obligation of each generation. Fish resources that exist in the territory of the country can come from the territory of other countries that migrate into the country, it is necessary to cooperate between countries as outlined in the agreement as described above. This cooperation is intended to nurture, protect the interests and prosperity of future generations.

International agreements that have been ratified in the field of fish resource conservation if observed, some are hard law and soft law. Pramudianto, 2008: 23) (15).Hard law includes laws that have a definite binding power (legally binding), whereas soft law is the legal elements that have no binding power to be sure. International agreements included in the hard law category United Nations Law of the Sea 1982, Agreement for the Implentation of the Provisions of the UNCLOS of 10 December 1982 Relating to the Conservation and Management of Stradding Fish Stocks and Highly Migratory Fish Stocks 1995, United Nations Convention on Biological Diversity 1992, and Convention International on Trade Endegered Species 1973. While the soft law category is CCRF 1995 and IPOA-IUU.

The types of international agreements of the hard laws category mentioned above are conventions and agreements. The type of agreement with the form of convention regulates the essentials and principles. Whereas the agreement form specifies particular things in particular. International agreement $s$ that have been ratified by Indonesia are multilateral, of course, each of these international agreements has principles. Principles that apply to international agreements such as the principle of good faith,pacta sunt servanda,and pacta tertiis nec nocent nec prosunt. As a participating country of international agreement, Indonesia has shown good faith to implement the agreement, especially in the field of fish resources conservation. Management of fisheries in marine territories within the control of a country based on the international treaties described above, basically the management and regulation, supervision and law enforcement are left to the policies of each country. Each country is entitled and responsible for the utilization activities of marine resources, especially fisheries, including the protection and preservation of its environment.

According to the authors there is an interlinked international agreement and complementary, in other words the international agreement is an overall system, legal system and environmental system. International treaties such as UNCBD 1992 regulate ecological systems primarily in protecting flora and fauna and their habitats through the conservation and protection and management of good biodiversity. UNCBD 1992 in its implementation will affect CITES 1973 which regulates trade in endangered species, and the UNCLOS 1982 agreement serves as the legal order for the seas and oceans, is a contribution to strengthen, "peace, security, cooperation and friendly relations among all nations". Therefore to protect fish resources, countries must sign agreement set forth in some international agreements, so that when problems arise concerning fisheries management, countries can cooperate in their handling.

\section{The concept of protection on fishery resource conservation in Indonesia}

Indonesian republic is a law state (rechtstaat) therefore the natural resources and ecosystem management are based on law in order to secure legal certainty in doing catching 
fish activities. Also the base of legal protection on fishery resource management and its ecosystem that is used as guidance in Indonesia is the implementation of International agreement which is explained previously. Also the concept of law on fishery resource conservation as follow:

\subsection{Law number 32 of 2009 on Living Environment}

Living environment in Indonesia as the ecology concept, its meaning is on article 1 number 1 Law number 32 of 2009 stated that: "Living environment is the unity of space with all things, source, condition, and living creature, including human being and its behavior, which influence the nature itself, the continuance of living, and the prosperity of human being and other living creatures." Based on that limitation, living environment is not separated by administrative region or country. If living environment is connected with its protection and management, then there should be a clear regional border protection and management. Indonesian living environment is not other than Nusantara region which locates cross position between two continents and two oceans with tropical climate and weather and season which give natural condition and position which has high strategic role on value, a place where Indonesian people and nation hold states chores in implementing protection and management of living creature is a Nusantara (Indonesia) Knowledge. (Syamsul Arifin, 2012: 67-68) (16).

Indonesia Knowledge which is covered in 4 important realizations:

a. the realization of Indonesia archipelago as one political unit,

b. the realization of Indonesia archipelago as one social and cultural unit,

c. the realization of Indonesia archipelago as one economic unit,

d. the realization of Indonesia archipelago as one security and defense unit.

According to international law, Indonesia archipelago as the realization of archipelago state has been recognized in the international sea law convention of 1982 (The International on the law of the Sea). 1982 convention is Law of the sea convention which is ruled the entire sea aspects including the management and the protection of the resource. According to the law, Indonesia has bounded to this convention and has caused right and responsibility which is applied by the Indonesian republic government.

The aims of management and protection of living environment according to article 3 of the law are as follow:

a. To protect the Indonesian republic regions from pollution and/or damage of living creature.

b. To guarantee the continuance of life of living creature and ecosystem preservation.

c. To keep the preservation function of living environment

d. To reach the harmony, conformity, balance of living environment

e. To guarantee the fulfillment of today and tomorrow's generation justice

f. To guarantee the fulfillment and protection of right on living environment as part of basic human right

g. To control the utilization natural resources wisely

h. To realize the continuance development and

i. To anticipate global environment issues

From the limitation above "protecting the preservation of living environment function" does not mean that the environment is preserved or static but the environment condition get development both through evolution process and revolution process. Well and healthy environment are the basic and constitutional rights of Indonesian people. The nation, government and stake holders have responsibility to protect and manage the living 
environment in implementing the establishment continuance so that the living environment of Indonesia can be the living and supporting resource for Indonesian people and other living creatures.

\subsection{Law number 31 of 2004 on fisheries junto law number 45 of 2009 about the amendment on fisheries Law of 2004}

A state area covers land, air and water. Indonesia has all of it so that our country has two forms of geographic as one character of a country which is an archipelago state and a land state. The geographical shape like this is a blessing from Allah SWT who creates and owns the universe.

The existence of fish resource which is found in Indonesia water is abundant, and can be managed and utilized to give benefits for nation and country, especially the entire society. In the dictum of Law number 31 of 2004 about fisheries has been emphasized that the water under the state of Indonesia jurisdiction and sovereignty and Indonesia Exclusive Economic zone and the ocean according to international rule including fish resources and a potential fish cultivation field.

Article 2 paragraph (2) Law number 31 of 2004 stated that the management of fisheries is done according to advantage, justice, cooperation, equality, cohesion, efficiency, and continuous preservation principals. While on the article 2 the law number 45 of 2009 about the amendment of Law number 31 of 2004 about fisheries stated that the fisheries management is done according to principals on (a) advantage (b) justice (c) togetherness (d) cooperation (e) independence (f) equality (g) cohesion (i) efficiency (j) perseverance (k) continuous development.

According to article 3 law number 31 of 2004 stated that the management of fisheries is applied aiming to:

a. To improve the living standard of small fishermen and the people who cultivate small fish

b. To improve the income and state devise

c. To push the expansion and job opportunity

d. To improve the availability and the consumption of fish protein source

e. To make the management of fish resources optimal

f. To improve the productivity, quality, additional value, and competitiveness

g. To improve the availability of raw materials for industry of fish management

h. To reach the utilization of fish resources, the field of fish cultivation, and fish resource environment optimally

i. To guarantee the perseverance of fish resource, the field of fish cultivation, spatial order

In the Law number 31 of 2004 according to article 4 stated that the Law functions for:

(a) Every individuals both native and foreign citizens and Indonesian and foreign corporate bodies which conduct activities of fisheries in the area of Indonesian republic fisheries management

(b) Every fisheries ship with Indonesian and foreign flags which conducting fisheries activities in the area of Indonesian republic fisheries management

(c) Every fisheries ship with Indonesian flag which conducting fish catching outside of Indonesian republic fisheries management area

(d) Every fisheries ship with Indonesian flag which conducting fish catching both as individuals and in groups, in the form of cooperation with foreign party. 
The implementation of Law on fisheries number 31 of 2004 is derived in the form of government regulation (PP) number 60 of 2007 about fisheries resource conservation, to rule more completely about the effort of ecosystem conservation management or fisheries habitat including the development of water conservation area as part of the ecosystem conservation.

According to article 2 paragraph (2), fisheries resources conservation is conducted according to principals: a) notice approach, b) consideration on scientific proof. c) consideration on local wisdom, d) management on society base, e) cohesion on development shore area, f) the avoidance of extra catching, g) the development fish catching tools and the strategy in catching fish environmentally friendly, h) a consideration on social economy condition of the society, and i) the utilization of continuous various biological resources. Previous rules are based on article $6 \mathrm{CCRF}$ on responsible fisheries management. (Yulia A. Hasan, 2015)(18).

The activities on fisheries resources conservation is the obligatory activities which is conducted by the government, local government and society especially fish farmer society or fishermen because for the society who dwells around the shore area and small islands rely on fish catching so that if there is conservation activities will impact the income and earnings of the fishermen society.

Fish resources is important as in the Law number 31 of 2004 constitute that about the conservation of fish resources which is conducted through ecosystem conservation, species ecosystem, and genetic conservation. An effort on fish resource conservation cannot be separated from the fish resource management and the whole environment. Noticing that fish resource characteristics and its environment has high sensitivity both from global climate effect and seasonal climate also some connectivity aspects of ecosystem among local, regional, global water area which is possibly cross the sovereignty border of a country. So that in the effort of fish resource conservation management and development should be based on carefulness principals with the support from scientific proof, as found in the implementation of law number 60 of 2007 about fish resource conservation. The explanation of fish resource conservation according to previous general constitution regulation: efforts on the protection, the perseverance and the utilization of fish resource including species and genetic ecosystems to guarantee the existence, the availability, and the continuance by keeping and improving the quality value and the variation of fish resource.

The area of water conservation is managed by the government and local government depending on their authorities according to article 16 paragraphs (1), (2), and (3) based on fishery Law. In relation with this the management of water conservation area which under the responsibility of government are:

a. The sea water beyond 12 mile which is measured from the shore line to the ocean or to the archipelagic water

b. The water which is under the responsibility area of cross province management, or

c. The water which has certain characteristics.

While the management of water conservation area which is conducted by the provincial government covers :

a. Sea water beyond 12 mile which is measured from the shore line to the reason and or to the archipelagic water.

b. The water conservation area which is under the responsibility of cross regencies/cities management. 
In determining the right, power, and responsibility in government field is not in the hand of central government but some have been given to the provinces and regencies/cities government as one of the authorities' right and the authorities in sea area management.

Indonesia Sea consists of internal waters, archipelagic waters, and territorial sea. (I Wayan Partiana, 2014:347). (19). If we notice Indonesian map, there is no single province in Indonesia which does not have beaches or sea areas. Some provinces in Indonesia have 12 sea mile at maximum to the archipelagic waters which is both are measured from the base line, such as Banten, West Java, central Java, east Java, Aceh, Bali, west Nusa tenggara and east Nusa tenggara while some provinces that facing the ocean, such as Yogyakarta, west Sumatera, and Bengkulu. Beside that there are some provinces that facing the archipelagic waters such as West Kalimantan, Central Kalimantan, South Kalimantan, West Sulawesi, South Sulawesi, Central Sulawesi and South-East Sulawesi.

Law number 27 of 2007 about the shore areas management and small island in the article 23 paragraph (2) constituted that the utilization of small islands and the water surrounded is prioritized for one of these interests: a. conservation; b. education and training; c. research and development; d. sea cultivation; e. tourism; f. Marine and fishery works and industries on fishery perseverance; g. organic farming; and/or h. farming; i. organic farming; j. livestock.

In point e above stated that the utilization of Island and the water surrounded can be used for tourism. To be able to use the shores and the island for tourism areas need a well preparation because without good planning it will cause damage to the natural resources which lay around the island and the shore. Indeed the beauty of the shore and the island which Indonesia has can attract many tourists to visit and of course it can increase the local income moreover if the places still maintain its cultural tradition values which is related with the island and the shore. The celebration or cultural tradition which is conducted once in a year in the beach can harm the beach environment for a long time later if there is no sufficient monitoring. Fish that usually live in the shore will move to the middle of the sea and slowly will go away. The impact is the fish resource in the shore will be decreased.

Therefore according to the article 27 paragraph (1), (2), and (3) the Law number 23 of 2014 about the local government regulate that provincial areas are given an authority to manage the sea natural resources within its area to the furthest 12 mile sea measured from the beach line to the ocean and/or to the archipelagic waters, which include:

a. Exploration, exploitation, conservation and the management of the marine resources beside oil and gas

b. Administrative regulation

c. Space regulation

d. Joining in the protection of sea security

e. Joining in the defense of state sovereignty

The management of water conservation areas could be done by the regencies/ cities authorities, which include: 1/3 sea water of provincial management authority areas: brackish water and fresh water under its authority areas.

Conservation areas consist of some zones and they are primary zone, continuous fisheries zone, utilization zone, and other zones. Conservation areas planning will be regulated later by the ministerial regulation.

In order to improve the quality and the quantity of the conservation implementation of the fishery resource needs person in charge of the implementation. If we refer to the regulation on the article 3 government regulation number 60 of 2007 stated that the fishery resource conservation under the responsibility of the government, local authorities, and the society. 
The fishery resources conservation management that has been explained in some previous regulation prove that Indonesian government is serious to protect the fish resource from the unwanted things that might happened. It is only that in the fishery law there in no regulation Stradding Fish Stocks and Highly Migratory Fish Stocks beside that the regulations on fish species which are protected are still limited. According to the author this problem in deciding the verification process and the regulation arrangement spend much time so that the fish resources come to an end. To anticipate this to happen the government needs to conduct cooperation with other countries.

Other than those challenges, the law enforcement in our country is considered law so that there is no different effect for the fishermen and the foreign traders, because so far the prevention of fish resources conservation only rely on single law instrument which is the Fishery law it also needs other law instrument to catch the criminals on fishery.

The author suggests the civil law enforcement instrument to be used as well which is a compensation and it is appropriated with the effect cause by the fish catching activity. Noticing that the fish resource can be used for the state and the society income through some activities, such as: catching fish both for consumption and tourism object. Therefore fish resource conservation must be given a special attention from the government regulation number 60 of 2007 about resource conservation. Fish and government concentration nowadays is to establish useful maritime in accordance with the government mission in the maritime context which is to realize Indonesia as independent, developed, strong country which based on the national interest.

According to the investigation found in international agreement data in the field of fish resource conservation that have been ratified by Indonesian government are as follow:

Table 1. International agreement ratification on the fish resource conservation field

\begin{tabular}{|c|c|c|c|}
\hline No. & International agreement & Ratification & Problem regulated \\
\hline 1. & $\begin{array}{l}\text { United Nations Convention on the } \\
\text { law of The Sea (UNCLOS) } 1982\end{array}$ & Law number 17 of 1985 & $\begin{array}{l}\text { Regulation on the sea } \\
\text { zones }\end{array}$ \\
\hline 2. & $\begin{array}{l}\text { Agreement for the Implementation } \\
\text { of the Provisions of the UNCLOS } \\
\text { of } 10 \text { December } 1982 \text { Relating to } \\
\text { the Conservation and } \\
\text { Management of Straddling Fish } \\
\text { Stocks and Highly Migratory Fish } \\
\text { Stocks } 1995 \text { or usually called } \\
\text { United Nations Fish Stocks } \\
\text { Agreement/UNFSA 1995 }\end{array}$ & Law number 21 of 2009 & $\begin{array}{l}\text { Regulation on } \\
\text { Straddling Fish Stocks } \\
\text { and Highly Migratory } \\
\text { Fish Stocks }\end{array}$ \\
\hline 3. & $\begin{array}{l}\text { Code of Conduct for Responsible } \\
\text { Fisheries } 1995\end{array}$ & $\begin{array}{l}\text { Adopted from the Law number } \\
31 \text { of } 2004 \text { about fishery jo. the } \\
\text { law number } 45 \text { of } 2009 \text { relating } \\
\text { to the amendment of the law } \\
\text { number } 31 \text { of } 2004\end{array}$ & $\begin{array}{l}\text { To regulate the ethics } \\
\text { code on responsible } \\
\text { fisheries }\end{array}$ \\
\hline 4. & $\begin{array}{l}\text { International Plan of Action to } \\
\text { Prevent, Deter and Eliminate } \\
\text { Illegal, Unreported, Unregulated } \\
\text { Fishing (IPOA-IUU) of } 2001\end{array}$ & $\begin{array}{l}\text { Decree of fishery and maritime } \\
\text { ministerial } \\
\text { NO.KEP50/MEN/2012 relating } \\
\text { to the national plan action to } \\
\text { prevent, deter and eliminate } \\
\text { illegal, unreported, and } \\
\text { unregulated fishing of 2012- } \\
2016\end{array}$ & $\begin{array}{l}\text { To regulate the } \\
\text { national plan action to } \\
\text { prevent, deter and } \\
\text { eliminate illegal, } \\
\text { unreported, and } \\
\text { unregulated fishing }\end{array}$ \\
\hline
\end{tabular}




\begin{tabular}{|r|l|l|l|}
\hline No. & International agreement & Ratification & Problem regulated \\
\hline 5. & $\begin{array}{l}\text { United Nations Convention on } \\
\text { Biological Diversity (UNCBD) }\end{array}$ & The law number 5 of 1994 & $\begin{array}{l}\text { To regulate relating to } \\
\text { the biological diversity }\end{array}$ \\
\hline 6. & $\begin{array}{l}\text { International Convention on } \\
\text { International Trade in } \\
\text { Endangered Species of Wild } \\
\text { Fauna and Flora (CITES) 1973 }\end{array}$ & $\begin{array}{l}\text { Government decree number 43 } \\
\text { of 1978 }\end{array}$ & $\begin{array}{l}\text { To regulate about } \\
\text { international trade in } \\
\text { Endangered Species of } \\
\text { Wild Fauna and Flora }\end{array}$ \\
\hline 7. & $\begin{array}{l}\text { FAO Agreement on Port State } \\
\text { Measures, 2009 }\end{array}$ & $\begin{array}{l}\text { Palidation agreement } \\
\text { on port state measures } \\
\text { Prevent, Deter and } \\
\text { Eliminate Illegal, } \\
\text { Unreported, regulation } \\
\text { Unregulated Fishing }\end{array}$ \\
\hline
\end{tabular}

Source: elaborated primary date, 2016

If we notice from the table above there are international agreements that have been ratified by the government which can be used right away as the source of the Law without necessity of regulation implementation which need to be adapted with the Indonesian law regulation such as the Law number 21 of 2009 relating to the regulation on conservation and the management Regulation on Straddling Fish Stocks and Highly Migratory Fish Stocks and there is also an international agreement that has been ratifies by the Indonesian government that still needs other regulations as the realization of its implementation for example UNCLOS 1982 which is ratified with the Law number 17 of 1985 that is later implemented on the Law number 6 of 1996 about Indonesian water. This shows that Indonesian government is not strict in regulating the implementation form of international agreement into national Law. The target of international agreement which is regulated the conservation of fish resource is the fish catcher or the fishermen lives in the country which obey the national Law and in contact with the sea environment directly beside having right to catch fish they also have to understand their responsibility in catching the fish so that the purpose written in the international law can be fulfilled.

\section{B. Factors that inhibits the right to catch fish for the fishermen in the activities of fish resource conservation}

The legislative regulation relating to conservation of fish resource was basically managed to avoid fishery from the negative impacts such as catching activities and for those who do not care about conservation of fish resources. According to Lawrence M. Friedman, (2001:285:286) (21), there are three things that are the foundation of the presence of good law order in the society, they are: Law substance, Law structure, and Law culture. The three of them should be in synergy in order to get affectivity in the law enforcement on fish resources.

While Anthony Allot (1981: 22) elaborates the factors that influence the ineffectiveness of the law, they are: 1)the imperfection on the formulas on law sentences in the regulation (the defects, of legal linguistics formulation), 2) the conflict between the interest of the Lawmaker and the willingness of the people which become the regulation target. 3) there is no implementation norms such as implementation regulation and institution which is responsible to make sure the implementation of legislative regulation.

Broadly, to guarantee the conservation of fish resources can be accomplished well so that in the article 7 paragraph (2) Fishery Law set responsibilities that must be obeyed in conducting effort or fishery management activities:

a) Type, number, and size of the catching tools including the size of the mesh 
b) Type, number, size, and location of the additional tools meaning for the facilities, tools, or other things that can be used to help the efficiency and the effectiveness of fish catching

c) Area, line, and time or season for catching the fish

d) Requirement or operational procedure standard in fish catching

e) Monitoring system of fishery ship

f) New fish type that will be cultivated

g) Type of fish and return spreading areas of fish disease

h) Fish cultivation and protection

i) Prevention, pollution, and damage of fish resource and its environment

j) The minimum size and weight of fish type that can be catched

k) Fishery sanctuary

1) Epidemic and epidemic areas of fish disease

m) Types of fish that is prohibited for trading, exporting from Indonesia and importing to Indonesian republic (NO.4.PERMEN-KP/2014, there is no reason why it is prohibited and need to be published and socialized).

n) Types of fish that is under protection (No. 35/PERMEN-KP/2013 relating to the ways for setting the fish protection status).

Those responsibilities mostly are put in the decree of fishery and maritime ministerial and refer to government regulation number 60 of 2007 fish resource conservation and the regulation has become the reference for the society in conducting fisheries management and fish catching.

If we look at the substances that are regulated in the legislative regulation in order to protect fish resource is actually adequate. It is just often cause pro and cons on the implementation of this regulation. For example in the regulation of the ministry of fishery and maritime No.2.PERMEN-KP/2015 about the prohibition to use fish catching tool such as trawls and Seine nets in the area of fishery management of Indonesian republic, there are some groups of Fishermen in Indonesia protested the implementation of ministry regulation almost 70 percent catching tools used by the fishermen are trawls by the implementation of that regulation can be felt as torturing the traditional fishermen and make them poor. It is one of the factors that influence the ineffectiveness of law which is the conflict between the lawyer maker and the willingness of the people which become the target of regulation as mentioned by Antony Allot.

The consideration by making the ministry regulation above that the use of fish catching tools such as trawls and seine nets in the fishery management area of Indonesia has caused the decreasing of fish resource and threatening the preservation of fish resource environment. Based on the research result shows that the sea exploitation in Indonesia is in the critical condition, the production in the headwater only 50\%. If we allow this to happen there will be a natural degradation such as the smaller size of the fish, it is not impossible will be disappear. (Yulia. 2017)(23).

In one side the government would like to enforce the regulation but another side the society feels that the regulation lessen their income, even many fishermen become jobless. What the government did was right by giving the transition time before implementing the regulation and the use fishing tools that are prohibited can only be used 12 mile from their sea areas.

In order to protect the continuance of fish resource beside ministerial regulation on fishery and maritime number 2 of 2015 also has been issued limitation to catch lobster 
(Panulirus SPP), Crabs (Syclla SPP), and small crab (portunus SPP) has been put in the ministry regulation number 1 of 2015 about the size of the lobster that can be catched is above $8 \mathrm{~cm}$ or equal with 300 gram, crab width $15 \mathrm{~cm}$ or equal with $350-450$ gram, small crab width $10 \mathrm{~cm}$ or equal with 55-8- gram according to the fact in the field there are still lobster trade. Crabs and small crab trade which is not fit the regulation and this trade usually are conducted by the fishermen in the middle of the sea working with receiver to sold to the society, not from the fish auction.

Basically the government protects the right of the fisherman in catching the fish because in the fish resource conservation there are three things need to be noticed protection, utilization and perseverance. Of course the fishermen has the right to utilize the fish resource by conducting catching activities but also need to notice the perseverance because fish resource need to be protected from the decreasing number and the types of fish resource can threaten its environment perseverance so that the cooperation between the government and the society in fish resource management is seriously needed. follows:

Generally the violation of fish resource conservation is caused by some factors, as

1. There Human behavior that cause negative impact that harm the fishery environment

2. There is a change in government policy related to a management conservation area which before is the authority local government the existence of new local government Law. That authority is given to provincial government. For example the absence of local regulation on fish resource conservation because the Law number 23 of 2014 about local government give authority to the provincial government to manage resource in the sea the furthest 12 mile sea (article 27) automatically the province should wait another local authority law.

3. Low enforcement on the law, this is related to the supervising, the reporting, and the trial. Generally the facilitation of the law enforcement on the fish resources conservation is as follow:

a. The administrative facilitation could be preventive and aim to enforce the legislative regulation. The enforcement can be applied toward the activities that are related to the permission requirement, the management of fishery, etc. administrative sanction mainly has instrumental function that is controlling prohibited actions. Beside that the administrative sanction mainly focuses in protecting interest which is protected by the regulation that is violated.

b. Criminal act facilitation conservation act of fish resource is regulated in article 84 till 93 in fishery law. In conservation case of fish resource currently in doing supervisory, the existence of compressor in the ship of fish catching, there is an indication of breaking the law.

According to Freed T. Wildes (Akhmad Fauzi, 2006: 13), that conservation of fish resources has genuine meaning including preservation and development concept of natural resources to human being needs on the earth nowadays and in the future. Therefore conservation implicitly including moral aspects and responsibilities to preserve, keep, secure, persevere the natural resources for today and tomorrow's generations. If morally and human responsibility are not implemented there should be sanction given to the human in accordance with the deeds. Noticing that the conservation of fish resources is ecological sentries that is how people and their behavior can keep the perseverance environment functions according to the purpose of fishery management and preservation that is to accomplish harmony, in accordance, and balance in the environment to guarantee the fulfillment of justice for 
nowadays and next generations. Therefore fishermen as one of the parties in the conservation of fish resource has the right and responsibility in doing fish catching activities in accordance with the regulation on fishery regulation as international agreement implementation that has been ratified by Indonesian government.

\section{Closing}

as closing, the author can summarizes some major points, they are:

a. The concept of legal protection on the fish catching done by the fishermen in conservation activities of fish resources in Indonesia cannot be separated from the international agreement that is agreed by the government of Indonesia. The protection on conservation of fish resources in Indonesia is the implementation of international agreement that is regulated the conservation of fish resources which are completed each other. However there are still some international agreements that have not been implemented in the national law and this situation influences the availability of fish resources because they can be taken by the foreign fishermen and it can harm Indonesia. To anticipate the international agreement that has not been implemented it is better to conduct a cooperation agreement with other countries to protect the fish resources which become the right of our fishermen.

b. Factors that inhibit the right of the fishermen to catch fish in the conservation activities of fish resources are : a. human behavior that give negative impact that harming the fishery environment, b. the government policy that is changed related to the management of conservation areas, c. the low enforcement of the our law

\section{References}

[1]. Article 2 Paragraph (2) government regulation number 60 of 2007 relating to conservation of fish resources:

[2]. Presented in the national seminar entitled "Rekonstruksi Ideal Eksekusi Tindak Pidana Perikanan, Antara Kaidah dan Harapan, " to celebrate the $22^{\text {nd }}$ anniversary of Persatuan Jaksa Indonesia (PJI) on $09^{\text {th }}$ June 2015 at Gedung Graha Pena, Makassar.

[3]. ${ }^{1}$ presented in the national seminar entitled "Rekonstruksi Ideal Eksekusi Tindak Pidana Perikanan, Antara Kaidah dan Harapan" to celebrate the $22^{\text {nd }}$ anniversary of Persatuan Jaksa Indonesia (PJI) by M.Nasir Jamil on $09^{\text {th }}$ June 2015at Gedung Graha Pena,Makassar.

[4]. Marcel Hendrapati, 2013. Implikasi Kasus Sipadan \& Ligitan Atas Titik Pangkal Dan Delimitasi. Arus Timur. Makassar. page125-126.

[5]. Seokwoo Lee, 2013, The Legal Assessment of the Illegal Fishing Activities of Chinese Fishing Vessels:A Focus on Detention of Foreign Vessels, Korean Journal of International and Comparative Law 1 . page 31-48

[6]. Dikdik Mohamad Sodik, 2011, Hukum Laut Internasional dan Pengaturannya DiIndonesia, PT Refika Aditama, Bandung, page 85

[7]. Muhammad Ashri.2012, Hukum Perjanjian Internasional Dari Pembentukan Hingga Akhir Berlakunya.Arus Timur.Makassar. page 82

[8]. Jesse Hasting,Safeguarding the Blue Planet : Six Strategis For Accelerating Ocean Protection,Parks-The International Journal of Proteted Areas and Conservation 2012.Vol.18, page 12 
[9]. Yusmanto, dkk.Pengelolaan Kawasan Konservasi Laut Daerah Ujungnegoro-Roban Kabupaten BatangJurnal EKOSAINS | Vol. IV | No. 3 | November 2012, page 49.

[10]. Guide Book, 2010. Jenis-Jenis Ikan Yang dilindungi Dan Masuk Dalam Appendiks CITES. Direktorat Konservasi Kawasan Dan Jenis Ikan Direktorat Jenderal Kelautan, Pesisir Dan PulauPulau Kecil Kementerian Kelautan Dan Perikanan. Page 2.

[11].Johanes Widodo, 2008, Pengelolaan Sumberdaya Perikanan Laut, Gadjah Mada University, Yogyakarta, page 195

[12].Dikdik Mohamad Sodik, 2014.Hukum Laut Internasional. Refika Aditama. Bandung. page 165

[13].Pramudianto, 2008 Diplomasi Lingkungan: Teori dan Fakta, Penerbit UI Press, Jakarta. page 23

[14].Syamsul Arifin, Hukum Perlindungan Dan Pengelolaan Lingkungan Hidup Di Indonesi, PT. Sofmedia, Jakarta, 2012, page. 67-68.

[15].Supriadi, 2011.Hukum Perikanan. Sinar Grafika. Jakarta.page .23

[16]. Yulia A.Hasan,Implementation ff international Instruments In Indonesian Legislation In The Field of Conservation of Fish Resources, JOURNAL OF HUMANITY, Vol. 3, No. 1, Feb. 2015, pp. 94-106

[17].I Wayan Parthiana, 2014.Hukum Laut Internasional dan Hukum Laut Indonesia. Yrama Widya, Bandung. page 347

[18].Lawrence M.Freieman (Penerjemah Wisnu Basuki), 2001, Amerikan Law An Introduction Second Edition (Hukum Amerika Sebuah Pengantar), PT.Tananusa, Jakarta, page 285-286.

[19]. Anthony Allot, 1981.The Effectiveness of laws, Symposium on International Perspectives of Jurisprudence Volume 15, Number 2 (Valparaiso University law Review,page 231-232

[20]. Yulia, Law Enforcement On Conservation of Fish Resources In Indonesia, Journal of Humanities And Social Science (IOSR-JHSS),Vol 22,Issue I, Ver.4 (January 2017) Page 64.

[21]. Akhmad Fauzi, 2006. Ekonomi Sumber Daya Alam dan Lingkungan. GramediaPustaka Utama. Jakarta.page. 13. 